\title{
Female Entrepreneurship a comparison between Mexico, Brasil and Chile
}

\author{
María Eugenia Elizundia \\ Profesor Investigador \\ Universidad Anahuac, México \\ meelizun@anahuac.mx
}

\begin{abstract}
The aim of this study was to analyze female entrepreneurship in Mexico, Brazil, and Chile using data obtained from the Global Entrepreneurship Monitor (GEM) for each country and to analyze, whether any of the key indicators have significant influence in the female entrepreneurial activity, comparing the results with total and male entrepreneurial activity and comparing the results in all three countries. Descriptive analysis and logistic regression was employed.

The results show that some of these factors do have a significant influence in female entrepreneurship, that they are the same on comparison with total and male entrepreneurship, and that these factors (except for believing that participants have the required abilities to start a business) are not the same when comparing all three countries.

There is still a lack of literature studies on this phenomenon, especially in Latin America. This study attempts to fill this gap.
\end{abstract}

Keywords: Entrepreneurship, women, Mexico, Brasil, Chile, GEM.

JEL: M1, L26, C4. 


\section{Resumen}

El objetivo de este estudio fue analizar el emprendimiento femenino en México, Brasil y Chile utilizando la base del Global Entrepreneurship Monitor (GEM), analizando si alguno de los factores clave tienen una influencia significativa en la actividad empresarial femenina, comparando los resultados con la actividad emprendedora total y masculina de cada país, y comparar si los resultados son los mismos en los tres países. Un análisis descriptivo y regresión logística fueron utilizados.

Los resultados muestran que algunos de estos factores tienen influencia significativa en el emprendimiento femenino, que estos son los mismos en comparación con el emprendimiento total y el masculino y que estos factores (a excepción de las oportunidades percibidas) no son los mismos cuando se comparan los tres países.

Actualmente existe una falta de estudios científicos de este fenómeno especialmente en América Latina. Este artículo intenta llenar este vacío

Palabaras clave: Emprendimiento, mujeres, México, Brasil, Chile, GEM.

\section{Introduction}

Over the last three decades, women's participation in new businesses has increased significantly, governments and national and international organizations are realizing that female entrepreneurship exert a positive impact on development in all countries. First, it increases economic growth, provides employment opportunities, is diverse and covers nearly all sectors of the economy (Weeks and Seiler, 2001).

Although the phenomenon is more relevant in developed countries, Latin American countries, including Mexico, Brazil and Chile, are no exception. However, these entrepreneurs continue to have important disadvantages that limit their access to economic development (Espinosa and Stiepoviæ, 2010; Loscocco, Robinson, Hall, and Allen, 1991). The nature and structure of entrepreneurial 
activities varies across countries and over time; therefore, if one is interested in studying entrepreneurship within or across countries, one should compare the countries under the same conditions and in similar situations (Kelley et al., 2013).

The difficult economic situation worldwide, including in Latin America, with a high unemployment rate in addition to females fulfilling the traditional family role, has made it necessary for many women to find some form of economic activity to provide income to help their families. The most recent Global Entrepreneurship Monitor GEM report (2014) shows important and constant growth in this phenomenon, but continues to present an important gap between the number of women involved in nascent and young entrepreneurship compared with that of men's. In Mexico, Brazil, and Chile, evolution of female entrepreneurial activity in the last decade has also been increasing (Figure 1) but its proportion remains lower than that of their male counterparts except for Brazil that, for the first time in 2014, demonstrated a higher rate of female than of male entrepreneurship (17.5\% vs. 17\%)(Table 1).

\section{Figure 1}

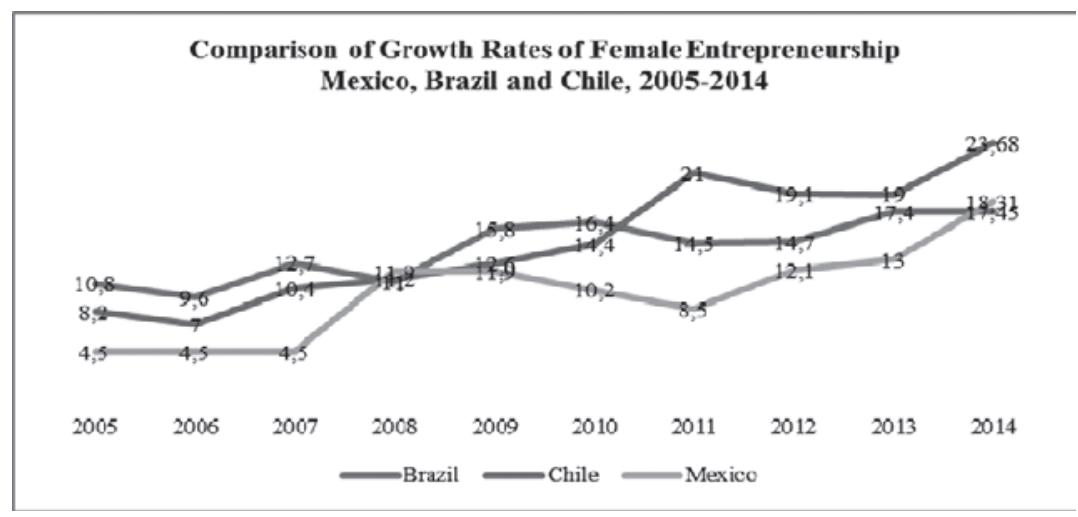

SOURCE: http://www.gemconsortium.org/Data. 


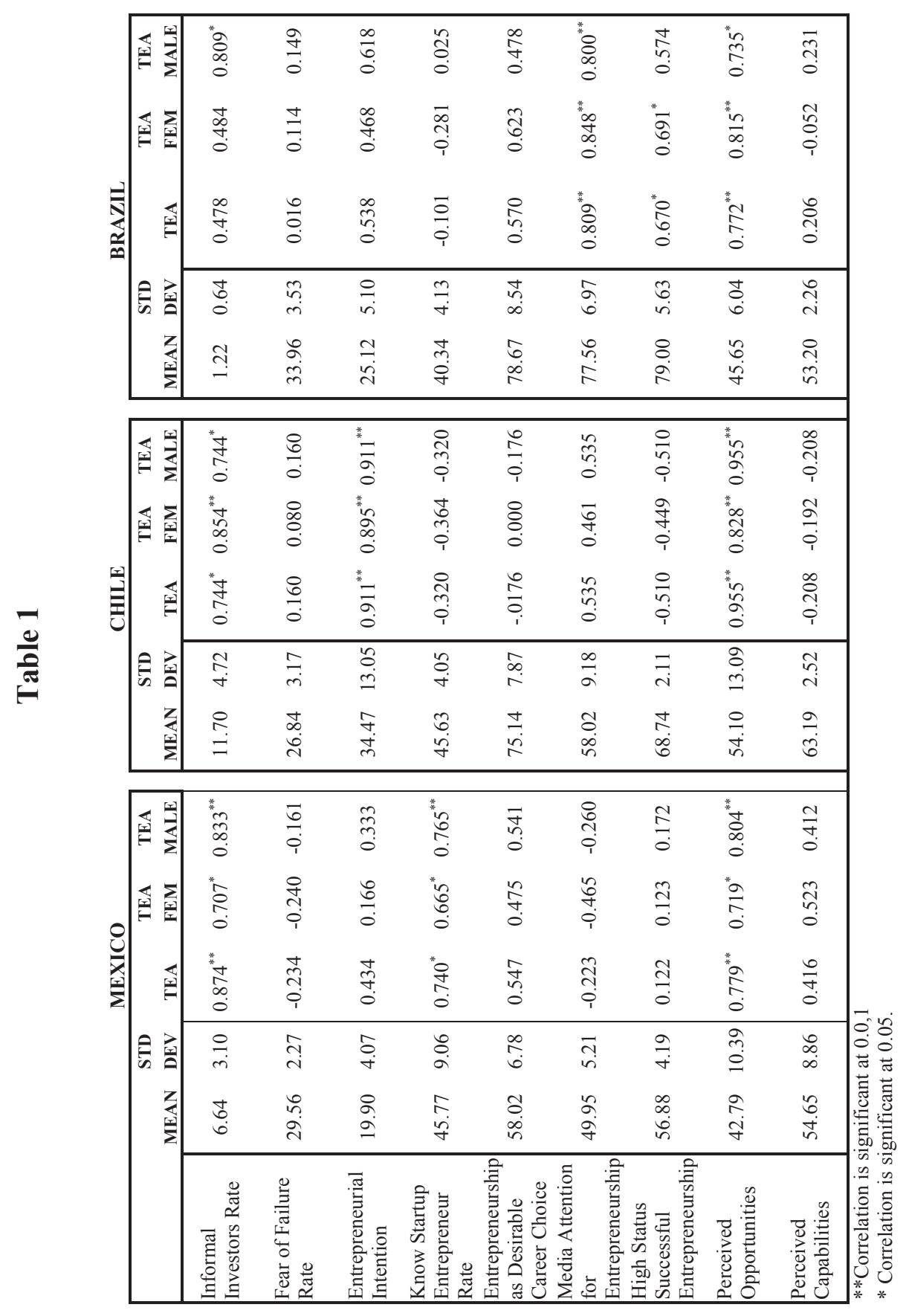


Although a growing body of research has begun to appear in different journals (Kelley et al., 2013; Terjesen and Amorós, 2010), limited attention continues to be paid to Latin-American countries. This study attempts to fill this gap by comparing and analyzing the different factors obtained from the GEM study for Mexico, Brazil, and Chile, and additionally reports whether there is a significant correlation between these factors and female entrepreneurship activity in each country, comparing these with total and male entrepreneurship and comparing the results in all three countries.

The main findings of this research show that the most relevant factors for female entrepreneurship in Mexico are informal investors and to know a startup entrepreneur while in Chile, these are informal investors and entrepreneurial intentions, and in Brazil, media attention and high social status. The sole factor that was relevant for all three countries in all three groups was perceived opportunities.

This paper is structured as follows: first, a review of the literature of the major studies that have explored this subject; from this review, the proposed hypotheses are derived and we present the methodology and database used, and finally, the results and conclusions are presented.

\section{Review of literature}

The study of female entrepreneurship dates back to the 1970. Until then, only males were the object of research studies on entrepreneurship (Ahl, 2006). Schwartz in 1976 was one of the pioneers in this area. In his article, he explored the motives of, characteristics of, personalities of, and difficulties faced by women entrepreneurs and concluded that the reasons why women started their own business were similar to those of men and that both had similar "entrepreneurial qualities and skills". However, he found that women faced more barriers that hindered their success, 
especially in obtaining financial resources (Ferraz Gomes, Pessoa Araújo, Fontes Martins, and Piau Santana, 2014).

During the 80s, several authors (Gartner, 1985; Verheul, 2009; Busenitz et al.,. 2003; Stevenson, 2006; Urbano and Álvarez, 2014, among others) began to discuss the factors that aided in and that might promote entrepreneurship, assuming that this phenomenon was generic and that its characteristics did not change except when compared with non-entrepreneurs. However, some studies (nearly all conducted in the U.S. and Europe) attempted to investigate the entrepreneurial females compared with entrepreneurial males, finding no relevant differences (Ferrás Gomes, et al., 2014). In the same decade, the presence of entrepreneurial women started to grow in nearly every sector of the economy. In 1991, Brush and Hisrich found that women continued to have difficulties related with accessing lines of credit and with obtaining guarantees due to their, although they had similar levels of education and experience.

In the late 90s, due to the world's economic and unemployment problem, research on female entrepreneurship continued to grow and began to discover that this type of entrepreneurship exerted an important impact on economic development, poverty reduction, and employment generation (Brush and Cooper, 2012). While research continued, several authors (Birley, 1989; Brush and Hisrich, 1991) demonstrated that men and women had differences in terms of background, experience, education, needs, perceptions, and motives. Also in that decade, Global Monitor Research (GMR), the largest cross-country set of entrepreneurship data in the world was inaugurated in 1999 as an ongoing project designed to collect comparable survey data across a large number of countries, and made an enormous contribution to this field by incorporating important methodology and data allowing comparison between an among countries presenting the relationship of this phenomenon with economic growth (Reynolds et al., 2005; Minniti, 2010; Ferrás Gomes et al., 2014). 
In this latter decade, the subject remains little studied compared with that of males. But knowledge has increased, showing that in the beginning, women's problems were mainly focused on financing and access to capital (Hughes et al., 2012) and these have currently evolved to the understanding that women's own aspirations, such as that females have a different type of ambition, a different definition of success, and that one of their main motives is to find a balance between work and family (Marković, 2007; Brush and Cooper, 2012). Also in this decade, the entrepreneurship process has evolved into an entrepreneurism phenomenon in which new entrepreneurs are expected to work in socially responsible ways, to create social as well as financial value, and not simply pursue individual self-enrichment (Rae, 2014).

The Global Entrepreneurship Report for Women (2012) reveals that at that time there were 126 million women aged 18-64 years who were involved in some sort of entrepreneurial venture around the world. These trends exhibit strong opportunities for research on this topic, especially in Latin America, because the majority of studies have been focused on the U.S. and Europe (Weeks and Seiler, 2001). A strong interest has begun to emerge from academia in this subject in all emerging countries.

Research Hypothesis:

Hypothesys 1

There are key indicators in the GEM study that have a significant effect in the probability of female entrepreneurship in Mexico, Brazil, and Chile.

Hypothesis 2

- $\quad$ These factors are the same as those in the total and male entrepreneurship groups in Mexico, Brazil and Chile. 
Hypothesis 3

- $\quad$ These key indicators are the same in these three countries.

\section{Methodology}

GEM was initiated in 1999 as a joint project between Babson College (Wellesley, MA, USA) and the London Business School (UK). The aim was to consider why some countries are more "entrepreneurial" than others. Currently, the GEM dataset comprise the richest resource of information on the subject and, unlike the majority of databases measuring entrepreneurship, the GEM (based on that entrepreneurship is a process) studies the individual characteristics of persons who start a business and the steps included in their gestation and formation (Amorós, 2011). Each country involved in the GEM Project participates with a mínimum of 2,000 interviews.

A figure for each of the key indicators is presented showing their trend for the last ten years. The mean, standard deviation and correlations were calculated between the factors and the dependent variables: Total (TEA), male (Teayymal) and female entreprenreuship (Teayyfem) in Mexico, Brazil, and Chile (Table 1).

Due to the binary nature of the dependent variables, a logistic regression was employed using The Adult Survey Population (APS) for the year 2011 for the three countries in order to identify which of the key indicators had significant effect in the probability of the dependent variables. Results are shown in Table 2 comparing the three groups and the three countries. 


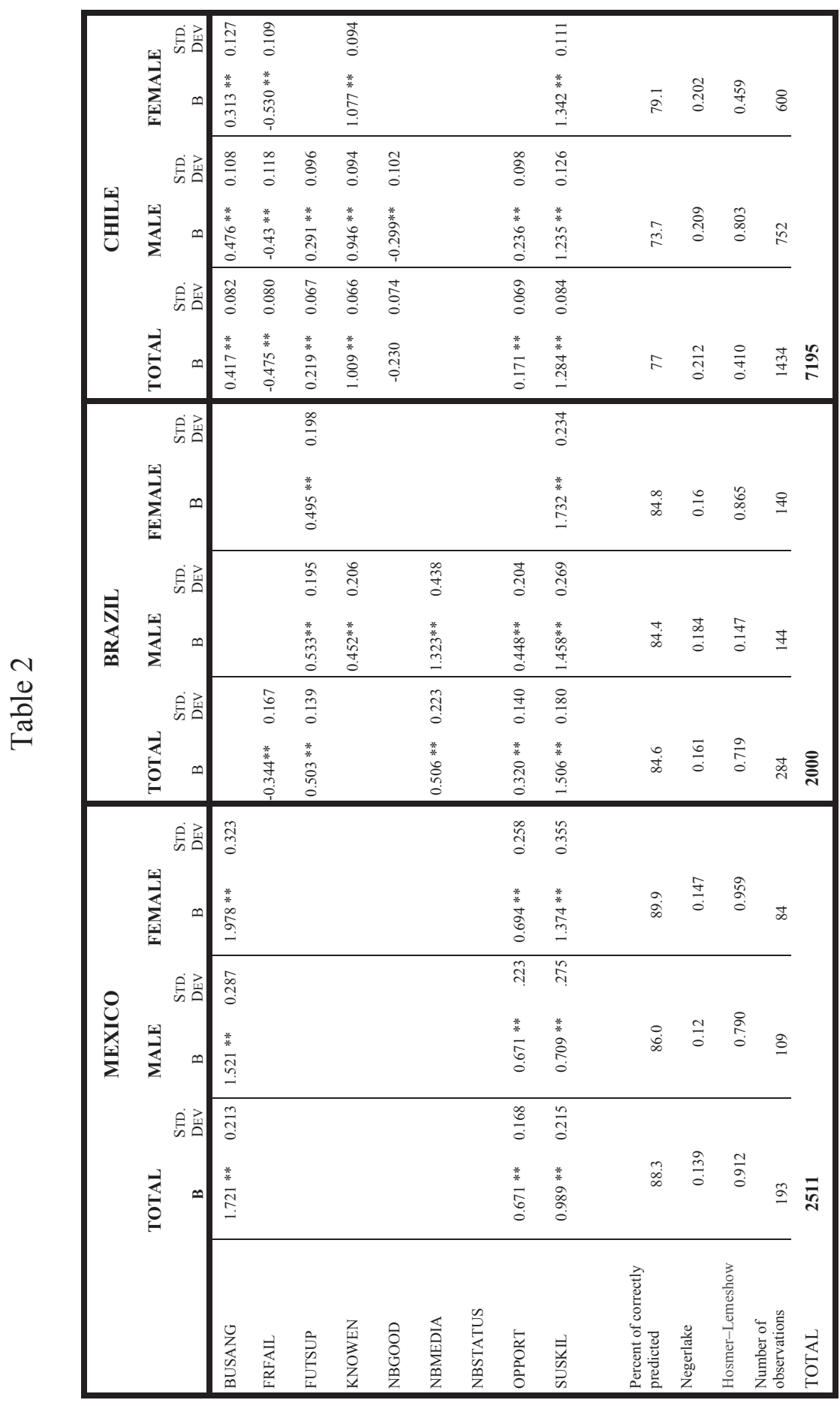




\section{Data an Variable Definition}

\section{A. Dependent Variables}

\begin{tabular}{|l|l|l|}
\hline Teayy & $\begin{array}{l}\text { Total early-stage } \\
\text { Entrepreneurial Activity } \\
\text { (TEA) }\end{array}$ & $\begin{array}{l}\text { Percentage of 18-64 population who } \\
\text { are either a nascent entrepreneur or } \\
\text { owner-manager of a new business. }\end{array}$ \\
\hline Teayyfem & $\begin{array}{l}\text { Total early-stage } \\
\text { Entrepreneurial Activity } \\
\text { for Female Working Age } \\
\text { Population }\end{array}$ & $\begin{array}{l}\text { Percentage of female 18-64 popu- } \\
\text { lation who are either a nascent } \\
\text { entrepreneur or owner-manager of a } \\
\text { new business. }\end{array}$ \\
\hline Teayymal & $\begin{array}{l}\text { Total early-stage } \\
\text { Entrepreneurial Activity } \\
\text { for Male Working Age } \\
\text { Population }\end{array}$ & $\begin{array}{l}\text { Percentage of male 18-64 population } \\
\text { who are either a nascent entrepreneur } \\
\text { or owner-manager of a new business. }\end{array}$ \\
\hline
\end{tabular}

\section{B. Independent variables}

\begin{tabular}{|c|c|c|}
\hline Busangyy & Informal Investors Rate & $\begin{array}{l}\text { Percentage of } 18-64 \text { population who } \\
\text { have personally provided funds for a } \\
\text { new business, started by someone } \\
\text { else, in the past three years. }\end{array}$ \\
\hline Frfailop & Fear of Failure Rate & $\begin{array}{l}\text { Percentage of } 18-64 \text { population with } \\
\text { positive perceived opportunities who } \\
\text { indicate that fear of failure would } \\
\text { prevent them from setting up a } \\
\text { business. }\end{array}$ \\
\hline Futsupno & Entrepreneurial Intention & $\begin{array}{l}\text { Percentage of } 18-64 \text { population } \\
\text { (individuals involved in any stage of } \\
\text { entrepreneurial activity excluded) } \\
\text { who intend to start a business within } \\
\text { three years. }\end{array}$ \\
\hline Knoentyy & $\begin{array}{l}\text { Know Startup } \\
\text { Entrepreneur Rate }\end{array}$ & $\begin{array}{l}\text { Percentage of } 18-64 \text { population who } \\
\text { personally know someone who } \\
\text { started a business in the past two } \\
\text { years. }\end{array}$ \\
\hline & & (Continue $)$ \\
\hline
\end{tabular}




\begin{tabular}{|l|l|l|}
\hline Nbgoodyy & $\begin{array}{l}\text { Entrepreneurship as } \\
\text { Desirable Career Choice }\end{array}$ & $\begin{array}{l}\text { Percentage of 18-64 population who } \\
\text { agree with the statement that in their } \\
\text { country most people consider } \\
\text { tarting a business as a desirable } \\
\text { career choice. }\end{array}$ \\
\hline Nbmediyy & $\begin{array}{l}\text { Media Attention for } \\
\text { Entrepreneurship }\end{array}$ & $\begin{array}{l}\text { Percentage of 18-64 population who } \\
\text { agree with the statement that in their } \\
\text { country, you will often see stories in } \\
\text { the public media about successful } \\
\text { new businesses. }\end{array}$ \\
\hline Nbstatyy & $\begin{array}{l}\text { High Status Successful } \\
\text { Entrepreneurship }\end{array}$ & $\begin{array}{l}\text { agree with the statement that in their } \\
\text { country, successful entrepreneurs } \\
\text { receive high status. }\end{array}$ \\
\hline Opportyy & Perceived Opportunities & $\begin{array}{l}\text { Percentage of 18-64 who see good } \\
\text { opportunities to start a firm in the } \\
\text { area where they live. }\end{array}$ \\
\hline Suskilyy & Perceived Capabilities & $\begin{array}{l}\text { Percentage of 18-64 population who } \\
\text { believe to have the required skills and } \\
\text { knowledge to start a business. }\end{array}$ \\
\hline
\end{tabular}

\section{Results}

\section{A. Informal Investor (Busangyy)}

Funding has always been an important issue in creating businesses. The main sources of funding for new ventures usually come from formal investors (bank loans), informal investors (persons who often have a family, friendship, or working relationship with the entrepreneur often invest small amounts without expecting an specific return) (Riding, 2008) and also the so called "Angel Investors" (people who have no prior relationship with the entrepreneur but who invest in the business because they see an opportunity that can afford them some kind of profit). They usually have experience in business, and, in many cases, not only provide capital, but also ideas, advice, and sometimes also end up becoming involved in the new venture (Bygrave and Kirchhoff, 2002). 
Given the entrepreneur's problems for gaining access to formal investment, Informal Investors and "Angels" have come to play important roles in the entrepreneurial process and are at the present one of main sources of entrepreneurial capital (Burke, Hartog, van Stel, and Suddle, 2010).

Research has shown that women present major obstacles for acquiring some type of formal or informal finance (Verheul et a.l, 2009) and, due to the growing importance of this group and its contribution to the economy, it is important for women to have access to a greater number of alternatives that allow them to obtain adequate financing and also to have greater exposure to these "Angel Investors" who, while their participation remains very low in Latin America, they have become an important financing resource.

As may be observed in Figure 2, for the last five years, the informal investors' rate has decreased for Chile and Mexico and has had a small increase in Brazil. In Table 2 the percentage of these informal investors presents positive effect $(p<0.05)$ in the total, the male and the female group in Mexico and Chile. It doesn't present any effect in Brazil

\section{Figure 2}

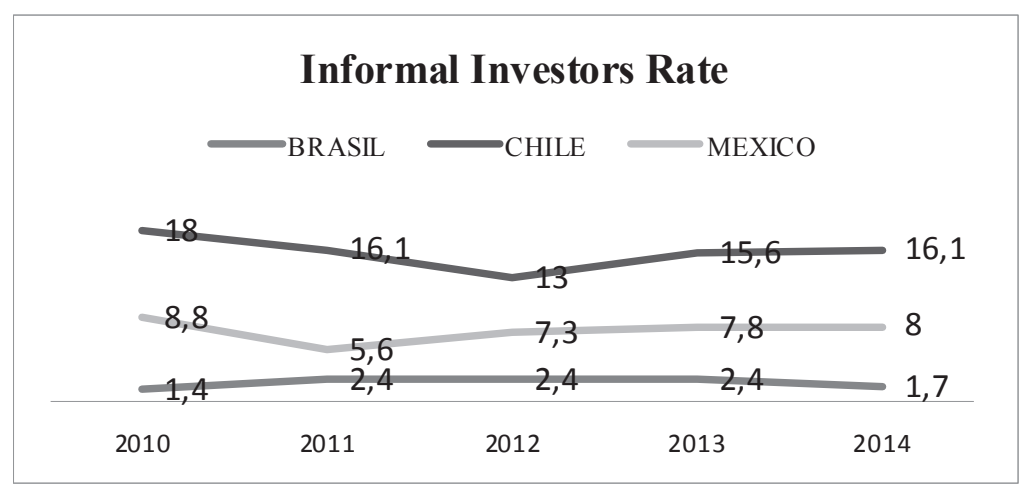

SOURCE: http://www.gemconsortium.org/Data. 


\section{B. $\quad$ Fear of Failure (Frailop)}

Fear of failure can be considered one of the main problems affecting future entrepreneurs. This fear affects entrepreneurship in both men and women because, although there are individuals able to identify opportunities and who think that they possess the skills and abilities to start a business, they might not come to carry out the process due to fear of failure, although this factor decreases when their country's level of development increases (Kelley et al., 2013). Lags in the environment increases the risk of failure of a business. It has been shown in several studies that women entrepreneurs are more risk averse and this entertain a negative connotation with regard to their level of development (Minniti, 2010; Díaz Casero et al., 2007; Carter et al., 2007).

It is noteworthy that there are not only success stories in the entrepreneurship process. It has been shown that for each success story, there is the likelihood of one or more stories of failure, which are also important to document. Educational and government programs should aid in reducing this fear and permit the observance of it as part of the normal process until the entrepreneur finds the right opportunity based on his/her own talents.

As we see in Figure 3, for the last five years, fear of failure has increased in Brazil and Chile, but decreased in Mexico (33\% to $28 \%$ ). Table 2 shows that this factor exerts a negative and significant effect $(p<0.05)$ in the total group in Brazil and in the total, male and female groups in Chile. It presents no effect in any of the three groups in Mexico. 


\section{Figure 3}

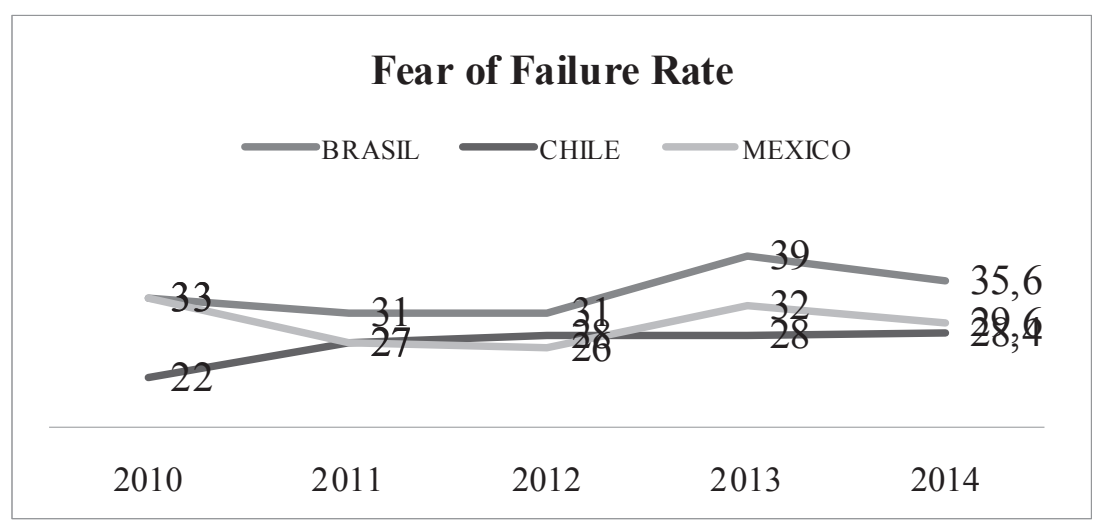

SOURCE: http://www.gemconsortium.org/Data.

\section{Entrepreneurial Intention (Futsupno)}

Entrepreneurship is not a simple act but instead occurs taking into account previous intentions, these representing a central aspect for understanding the entrepreneurship process and, in addition, these should be considered he first step in the creation of a new venture (Lee and Vivarelli, 2006; Carsrud and Brännback, 2011). However it is generally accepted that males have stronger entrepreneurial intentions than females (de Bruin et al., 2007; Díaz-García and Jiménez-Moreno, 2010).

There has been an important growth in research with respect to intentions and entrepreneurship in the last two decades (Wilson et.al., 2007). Some authors (Díaz-García and Jiménez-Moreno, 2010; Ventura y Fernández 2013) showed that intentions possess a strong predictive capacity in new venture formation and that females compared with males presented lower intentions. Additionally Shah and Soomro (2015) reported that entrepreneurial intention has been significantly and positively correlated with attitudes toward entrepreneurship. 
Analyzing the trends across the last five years in Figure 4 the only one of the three countries that presents an important increase in entrepreneurial intentions is Chile from $(38.3 \%$ to $50.1 \%)$ with Brazil maintaining nearly the same growth level while decreasing by two percentage points from 2010-2014, but in Mexico presenting an important decrease of nearly 5 percentage points $(22.3 \%$ to $17.4 \%)$.

\section{Figure 4}

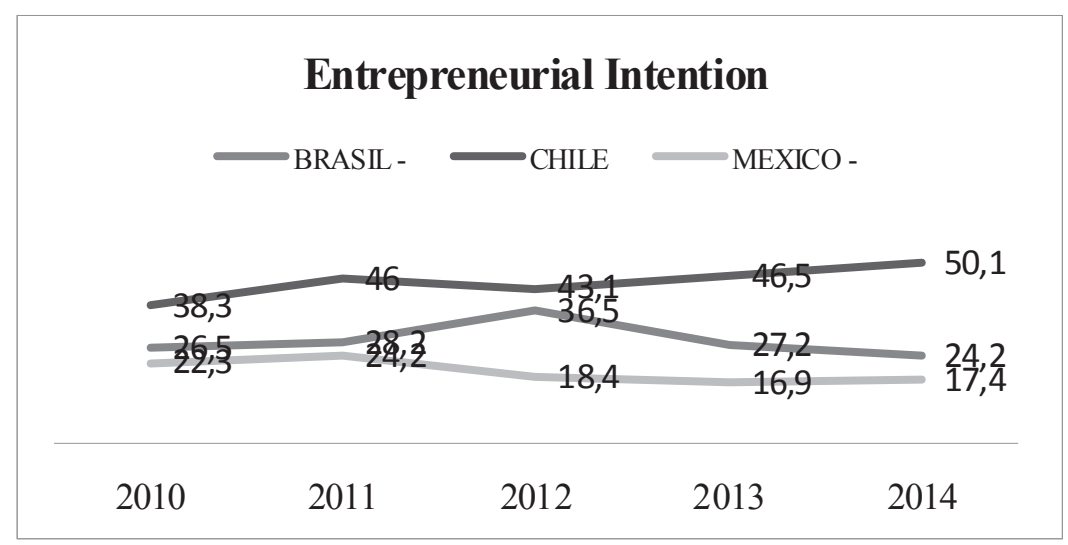

SOURCE: http://www.gemconsortium.org/Data.

The number of individuals involved in any stage of entrepreneurial activity, including those who intend to start a business within three years, presents a positive and significant effect $(p<0.05)$ in total, male and female groups in Brazil in the total and male group in Chile and does not demonstrate any relationship with the dependent variable in any group in Mexico (Table 2).

\section{Know Startup Entrepreneur Rate (Knoentyy)}

Social support networks and being in contact with other new and with established entrepreneurs comprise an important factor in the decision-making, creation, and implementation of a business. In the 
GEM study, this indicator is defined as the percentage of the population who personally know an entrepreneur. Several studies have shown the positive impact that knowing other entrepreneurs exerts, because this provides motivation for and confidence in entrepreneurship. Also, business owners and other entrepreneurs who have closed their businesses constitute a large and important resource of knowledge for new entrepreneurs (Arenius and Minniti, 2005).

Entrepreneurial social networks built by women are similar to those of men but are usually less extensive and less diverse (there are no studies reporting that in any country these networks are higher in women than in men), relying primarily on the support of family members and other women (Gatewood et al., 2009; Minniti, 2010; Díaz and Jiménez, 2010)

As depicted in Figure 5, this factor has decreased in Mexico since 2010 (in 2013 it underwent an important increase, but decreased again in 2014 by nearly 10 percentage points). In Chile and in Brazil, this factor also decreased across the last 5 years.

\section{Figure 5}

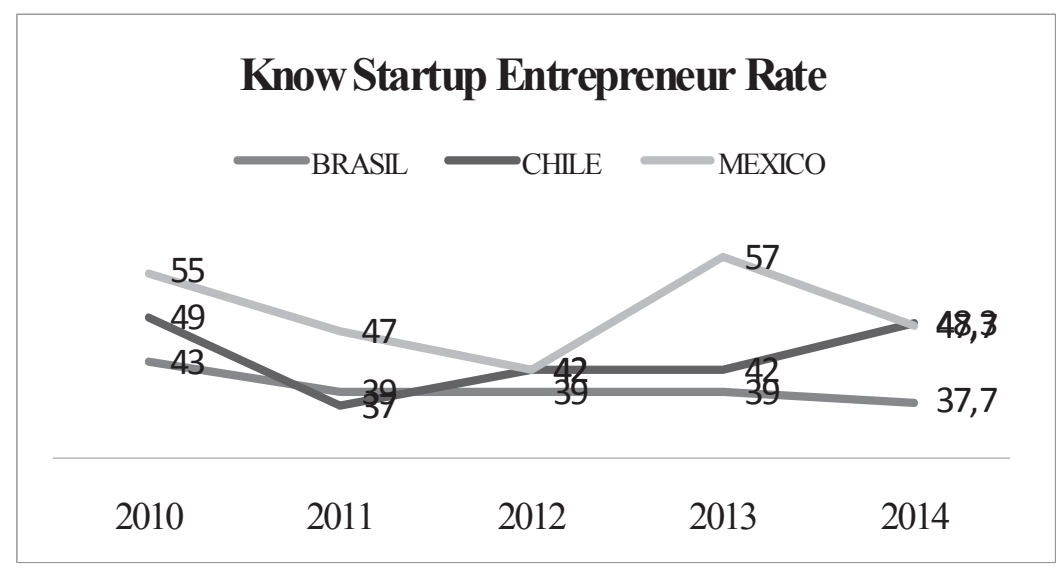

SOURCE: http://www.gemconsortium.org/Data. 
As may be observed in Table 2, the percentage of 18-64 population who personally knew someone who started a new business exhibit a strong positive effect $(p<0.05)$ in the male group in Brazil and in the total, male and female group in Chile. It shows not having any significant effect in any group in Mexico.

\section{E. Entrepreneurship as Desirable Career Choice (Nbgoodyy)}

Entrepreneurship research initially started analyzing why people chose to be an entrepreneur, predominantly through the disciplines of Psychology and Sociology. Recently, there has been an important increase in contributions on this topic from an economic perspective (Douglas and Shepherd, 2002).

Many persons who are employees at present are afraid to make a job change due to concern about the loss of health and social benefits. For others, the advantage of business ownership outweighs the risks, although there is a strong belief that entrepreneurship involves too much risks (only 5\% of new businesses survive after 3 years) (Fritsch, Brixy, and Falck, 2006). But the global economic and employment crisis and amazing success stories of young entrepreneurs, have promoted an increase in this type of employment. In some countries, entrepreneurship is viewed as a last resort, but during these last two decades, it has gained acceptance and legitimacy (Kelley et al., 2013).

Due to its familiar and social characteristics, entrepreneurship has become a desirable career choice for women because, although in many instances they are in search for a higher income, it also provides women with more independence and flexibility and a better balance between work and family (Collins-Dodd, Gordon, and Smart, 2004; DeMartino, Barbato, and Jacques, 2006).

As illustrated in Figure 6, the variable that measures the percentage of 18-64 population who agree that starting a business as a desirable career choice exhibit an increase only in Brazil, and very 
important decreases in Chile (87\% to $69.4 \%$ ) and in Mexico (69\% to $53.2 \%)$. It presents a negative significant effect $(p<0.05)$ in the total and male groups only in Chile. It does not present any significant results for any group in either Mexico or Brazil (Table 2).

\section{Figure 6}

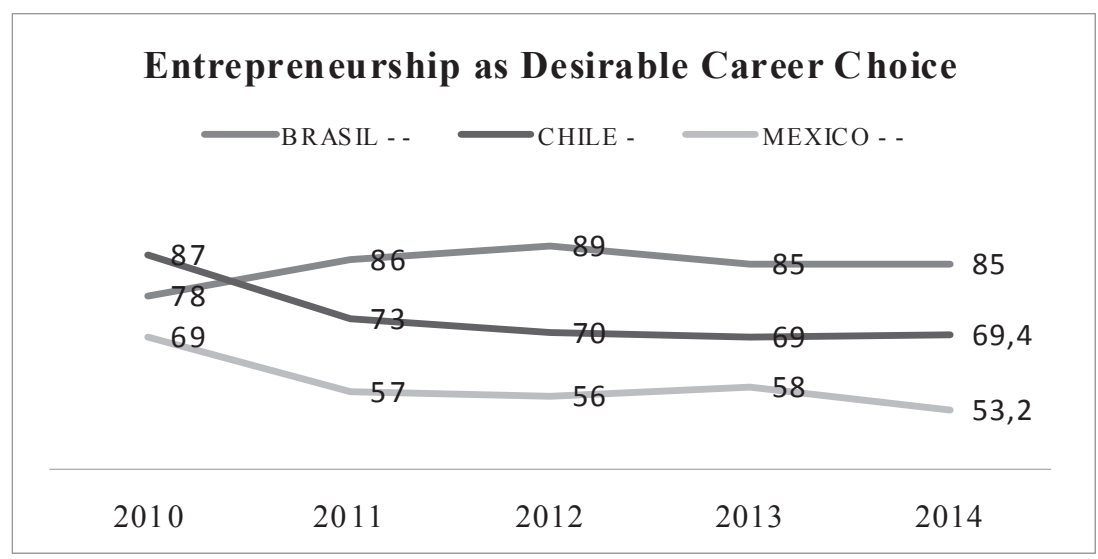

SOURCE: http://www.gemconsortium.org/Data.

\section{F. $\quad$ Media Attention (Nbmediyy)}

Another social aspect that impacts the entrepreneurial environment refers to the interest of the media in covering stories about entrepreneurial success. In the majority of advanced countries, the results show that the media devotes sufficient time and attention to successful entrepreneurs, creating a positive environment for entrepreneurship. In his study, Urbano et al., (2014) demonstrated that high media attention toward new businesses increases the likelihood of a person becoming an entrepreneur.

As a country's development level increases, media attention regarding entrepreneurship decreases, this having an important impact on entrepreneurship, which also decreases. This suggests that 
media attention may have more importance than would appear, because it has been observed that this factor along, with education, has a long-term effect on the attitudes of society toward entrepreneurship (Kelley et al., 2013). The stories told through the media have an important impact on new businesses because they make it easier to identify nascent entrepreneurs and to legitimize these, but they are also very important for investors, banks, foundations, and other institutions (Wry et al., 2011). Two decades ago, women's businesses were considered small and not important; thus, they did not receive attention from the media (Baker, Aldrich, and Nina, 1997). Due to the importance that this phenomenon has gained, this is beginning to change, although it continues to attract less attention than males receive (Kelley et. al., 2013)

Figure 7 illustrates that the trend of the variable that measures how often the population sees stories in the public media on successful new businesses for the last 5 years, depicting a small increase in Brazil (81\% to $84 \%$ ), but a very important increase in Chile (46\% to 65\%). In Mexico, this factor fell nearly 10 percentage points $(54 \%$ to $45.5 \%)$. Statistically, this variable presents a positive effect $(p<0.05)$ in the total and male group only in Brazil, but shows no type of effect in either Mexico or Chile (Table 2).

Figure 7

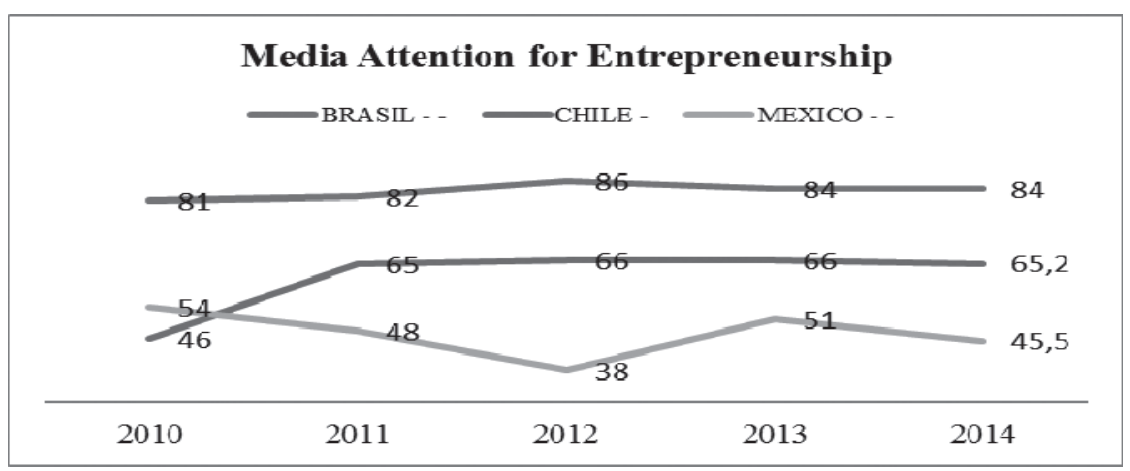

SOURCE: http://www.gemconsortium.org/Data. 


\section{G. Social Status (Nbstatyy)}

The next factor to analyze is social status, which measures the perception of individuals about what their closest relatives think about their forming a company (Krueger and Brazal, 1994) and the degree to which the society assigns high or low recognition to persons pursuing opportunities and taking risks (Abebe, 2012).

The social status process combines several complex behaviors that are developed depending on the cultural and social conditions in each country. The positive or negative perception that society has of entrepreneurship can influence the motivation of individuals to start a business; thus, it is important to continue promoting this as a source of inspiration and as socially desirable. For a long time, this factor possessed a negative connotation because it was thought that the entrepreneur was someone who had been unable to find work and had no other way to survive except for selfemployment (Kelley et al., 2013). The environment has changed and the entrepreneur has managed to gain respect and recognition. Currently, over one half of the population thinks that entrepreneurs enjoy high social recognition and prestige (Díaz Casero et al., 2007), although it has been shown that gaining status is more important for women than for men (Manolova, Brush, and Edelman, 2008).

This variable, which measures the manner in which successful entrepreneurs receive high status in each of the three countries, as we may note in Figure 8, has experienced a small increase only in Brazil (79\% to $82 \%$ ), a decrease in Chile $(71 \%$ to $64.4 \%$ ), and in Mexico, social status fell nearly 12 percentage points in the last year and exhibited a difference of nearly 30 percentage points in the last year as compared with Brazil. Additionally, this factor exhibits no type of relationship in either group in either country (Table 2). 


\section{Figure 8}

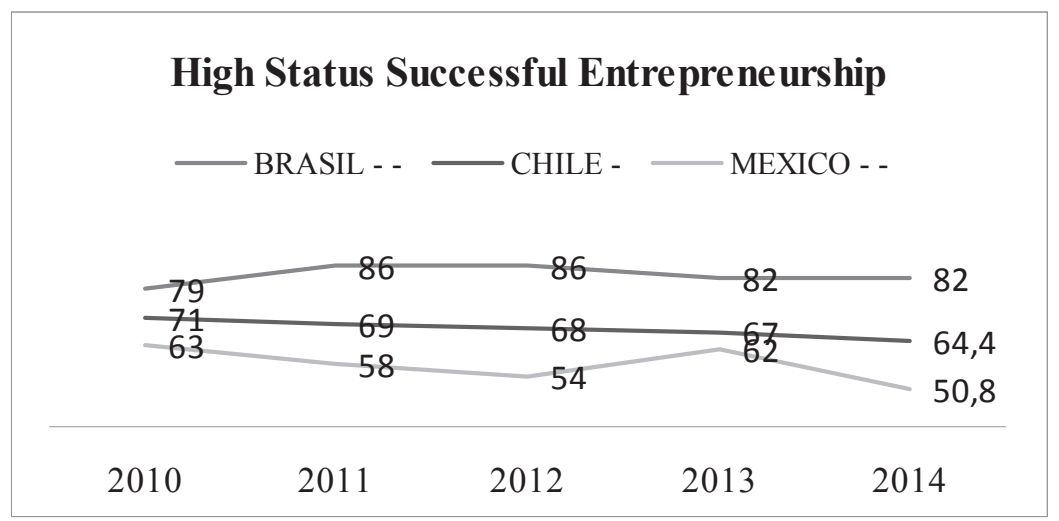

SOURCE: http://www.gemconsortium.org/Data.

\section{H. $\quad$ Perceived Opportunities (Oppotyy)}

Shane and Venkataraman (2000) define entrepreneurship as the study of sources of opportunities, because opportunity recognition represents the most distinctive and fundamental expression of entrepreneurial behavior. Dettienne and Chandler (2007) and Guzmán and Rodríguez (2008) found that males and females employ different ways to identify opportunities and each has different clusters of knowledge and perceptions. The relationship between perceived skills and identifying opportunities suggests that in societies where women think that they possess the skills and capacities, they are more likely to identify business opportunities, although these perceptions are likely to be affected by each country's economic cycle (Quevedo et al., 2010; Noguera et al., 2013).

There is sometimes the perception that opportunities exist but that they do not necessarily transform into new businesses because they often appear in different forms and at different times (Henley, 2007). Research has shown, especially in Latin America, 
that there is a positive correlation between the perception of business opportunities and the number of people involved in different types of entrepreneurial activity (Romaní et al., 2012).

We may observe in Figure 9 that the effect of the perception of good opportunities to start a firm in the area where the person lives has maintained its levels in all three countries. Brazil had the highest level, presenting a difference in the last year of 11.5 percentage points and 18.1 percentage points compared with Chile and Mexico, respectively.

This factor has a positive and significant effect $(p<0.05)$ in the total, male and female groups in Mexico and in the total and male groups in Brazil and Chile (Table 2).

\section{Figure 9}

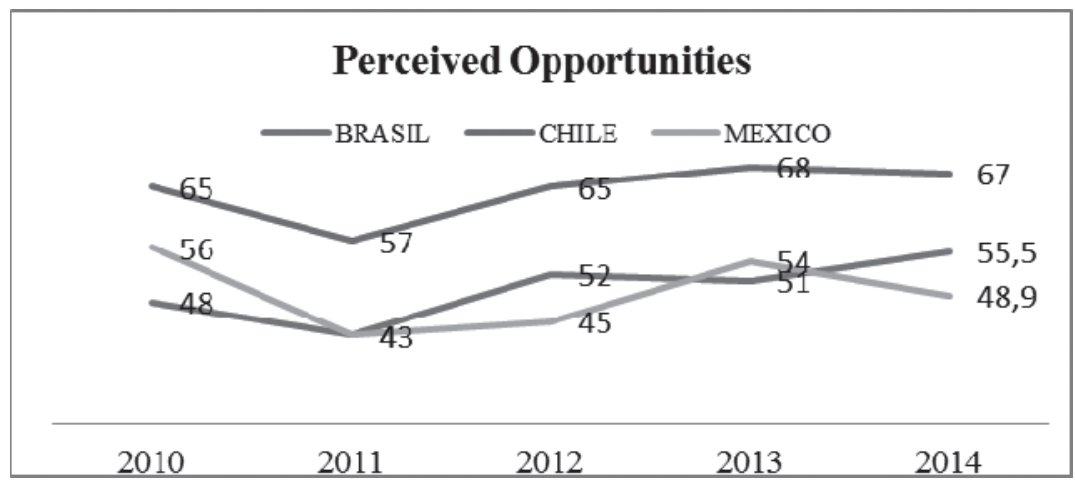

SOURCE: http://www.gemconsortium.org/Data.

\section{I. $\quad$ Perceived Capabilities (Suskiliyi)}

Perceived capabilities play an important role in the entrepreneurial decision. Many authors think that males and females think the same way when they value their knowledge, skills, and experience in terms of starting a new business (Hamilton, 2003; Birley, 1989). 
Other authors' report that compared with males, females have a reduced perception of their own capabilities independent of their real skills (Minniti, 2010; Wilson et al., 2007). In some countries, women may have more years of education than men, but sometimes this does not directly relate with their self-perceived confidence and entrepreneurial capabilities (Brush et al., 2012). In their study, Noguera et al., (2013) demonstrated that perceived capabilities was one of the most important factors in the probability of a female becoming an entrepreneur.

Although Figure 10 illustrates that this factor has decreased in all three countries in the last 5 years, especially in Brazil $(58 \%$ to $50 \%$ ) and Mexico (65\% to $53.5 \%$ ), thinking that one possess the required skills and knowledge to start a business is the only variable that exerts a positive effect $(p<0.05)$ in all three groups in the three countries (Table 2).

\section{Figure 10}

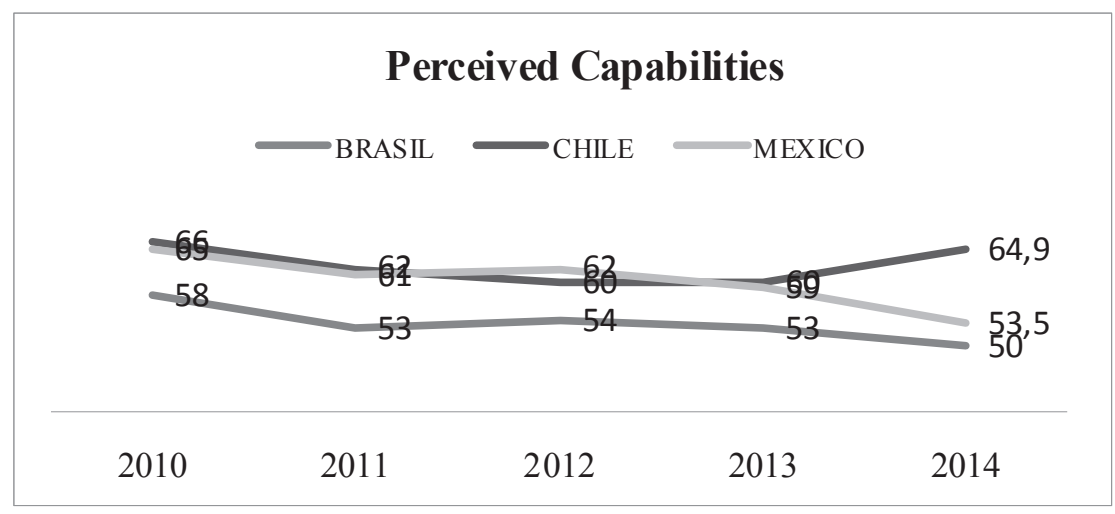

SOURCE: http://www.gemconsortium.org/Data. 


\section{Conclusion}

The objective of this paper was to analyze the relationship of the key factors of the GEM study with female entrepreneurship in Mexico, Brazil, and Chile.

Hypothesis 1: proposed that some key indicators in the GEM study had an important effect in female entrepreneurship in Mexico, Brazil, and Chile, which is confirmed.

Hypothesis 2: proposed that these factors were the same in total and male entrepreneurship in Mexico, Brazil, and Chile. This hypothesis is accepted because in all three countries, the factors that exerted influence on the female group are the same factors for the male and the total group.

We found that for Mexico, the factors that appear to exert the most significant effects in the female group are informal investors' rate and to feel that there are good opportunities to start a firm in the area where they live, while in Chile, these factors are informal investors' rate, fear of failure and to personally know someone who started a business in the past two years and for Brazil, the rate of entrepreneurial intention. The sole common factor in all three countries in the female group is to believe that they have the required skills and knowledge to start a business. Because Brazil is the only country presenting a strong effect between media attention and total and male entrepreneurship, suggests that policy-makers should insert more stories of male and female entrepreneurs into the media, especially in Mexico and Chile.

Hypothesis 3: proposed that these key indicators were the same in these three countries, which is not accepted; each country has its own influential factors being the only common factor to perceive that you have the required skills and knowledge to start a business. 
This study makes important contributions. First, it presents evidence of three of the most important economies in Latin America. Second, it helps to acquire better understanding of the factors that may contribute to female entrepreneurship compared with male entrepreneurship and also attempts to increase knowledge of female entrepreneurship in Latin America.

Due to the fact that increasing numbers of women are involved in starting their own businesses, research on this topic must continue to increase. Trends identified in the GEM study indicate opportunities for investigating this phenomenon in developing countries, and it will be interesting to find whether the results could be compared with those of other countries. 


\section{References}

ABEBE, M.A. (2112), "Social and Institutional Predictors of Entrepreneurial Career Intention: Evidence from Hispanic Adults in the U.S.", Journal of Enterprising Culture, Vol. 20(1), pp. 1-23.

AHL, H. (2006), "Why Research on Women Entrepreneurs Needs New Directions", Vol. 30, pp. 595-621. doi: doi: 10.1111/j.1540-6520.2006. 00138.x

AMORÓs J.E. (2011), "El proyecto Global Entrepreneurship Monitor (GEM): una aproximación desde el contexto latinoamericano", Academia, Revista Latinoamericana de Administración, Vol. 46, pp. 1-15

AreniUs, P. and M. MinNitti (2005), "Perceptual Variables and Nascent Entrepreneurship", Small Business Economics, Vol. 24(3), pp. 233, doi:10.1007/s11187-005-1984-x

BAKER, T., E. AlDRICH and L. NiNA (1997), "Invisible entrepreneurs: the neglect of women business owners by mass media and scholarly journals in the USA", Entrepreneurship \& Regional Development, Vol. 9(3), pp. 221-238.

BIRLEY, S. (1989), "Female Entrepreneurs: are the really any Different?”, Journal of Small Business Management, Vol. 27(1), pp. 32-37.

BRUSH, C.G. and S.Y. COOPER. (2012), "Female entrepreneurship and economic development: An international perspective", Entrepreneurship \& Regional Development, Vol. 24(1), pp. 1-6. doi: 10.1080/08985626. 2012.637340.

BRUSH, C.G. an R.D. HISRICH (1991), “Antecedent influences on womenowned businesses”, Journal of Managerial Psychology, Vol. 6(2), pp. 9-16.

Burke, A., C. Hartog, A. Van Ste and K. Suddle. (2010), "How does entrepreneurial activity affect the supply of informal investors?", Venture Capital, Vol. 12(1), pp. 21-47. doi: 10.1080/13691060903435775.

Busenitz, L., P. West, D. Shepherd and T. Nelson (2003), "Entrepreneurship research in emergence: Past trends and future directions", Vol. 29(3), pp. 285. 
Bygrave, W. and B. KirchHoff (2002), "The Portable MBA in Entrepreneurship" (Second Edition ed.): John Wiley and Sons.

CARSRUd, A. and M. BRÄNNBACK (2011), "Entrepreneurial Motivations: What Do We Still Need to Know?", Journal of Small Business Management, Vol. 49(1), pp. 9-26. doi: 10.1111/j.1540-627X.2010.00312.x.

CARter, S., E. Shaw, W. LAM and F. WiLsOn (2007), “Gender, Entrepreneurship, and Bank Lending: The Criteria and Processes Used by Bank Loan Officers in Assessing Applications", Entrepreneurship Theory and Practice.

Collins-Dodd, C., I.M. Gordon an C. SMART (2004), "Further Evidence on the Role of Gender in Financial Performance", Journal of Small Business Management, Vol. 42(4), pp. 395, doi: 10.1111/j.1540-627X.2004. 00119.x.

De Bruin, A., C.G. Brush and F. Welter (2007). Advancing a Framework for Coherent Research on Women's Entrepreneurship, Entrepreneurship: Theory \& Practice, Vol. 31(3), pp. 323. doi: 10.1111/j.1540-6520.2007. 00176.x

De Martino, R., Barbato, and P.H. JACQues (2006), Exploring the Career/Achievement and Personal Life Orientation Differences between Entrepreneurs and Nonentrepreneurs: The Impact of Sex and Dependents. Journal of Small Business Management, Vol. 44(3), pp. 350. doi: 10.1111/j.1540-627X.2006.00176.x

DE TIENNE, D. R. and G.N. CHANDLER. (2007), "The role of gender in opportunity identification", Entrepreneurship theory and practice, Vol. 31(3), pp. 365-386.

Díaz Casero, J.C., R. Hernández and M. Barata (2007), "Estudiantes universitarios y creación de empresas. Un análisis comparativo entre España y Portugal", Conocimiento, innovación y emprendedores: camino al futuro.

DíAZ GARCÍA, C. y. J. JiMÉNEZ (2010), "Recursos y resultados de las pequeñas empresas: nuevas perspectivas del efecto del género", Cuadernos de Economía y Dirección de Empresa, Vol. 42, pp. 151-176.

Douglas, E. J. and D.A. SHEPHERD (2002), "Self-employment as a career choice: Attitudes, entrepreneurial intentions, and utility maximization". 
EsPinOsA, J.E.A. and O.P. STIEPOVIÆ (2010), "Mujeres y dinámica emprendedora: un estudio exploratorio", Revista Universidad \& Empresa, Vol. 8(11).

Ferraz Gomes, A., U. Pessoa Araújo, C.M. Fontes Martins and W.G. Piau SANTANA (2014), "Empreendedorismo Feminino como Sujeito de Pesquisa" (Portuguese), Female Entrepreneurship as Subject of Research" (English), Vol. 16(51), pp. 319-342. doi: 10.7819/rbgn. v16i51.1508.

FRITSCH, M., U. BRIXY and O. FALCK (2006), "The Effect of Industry, Region, and Time on New Business Survival - A Multi-Dimensional Analysis", Review of Industrial Organization, Vol. 28(3), pp. 285-306. doi: 10.1007/s11151 -006-0018-4

GARTNER, W. (1985), “A conceptual framework for describing the phenomenon of new venture creation”, 10(000004), 696.

Gatewood, E., C. Brush, N. Carter, P. Greene and M. Hart (2009), "Diana: a symbol of women entrepreneurs' hunt for knowledge, money, and the rewards of entrepreneurship", Small Business Economics, Vol. 32(2), pp. 129-144. doi: 10.1007/s11187-008-9152-8

GuZmán, J. y. R. M. J. (2008), “Comportamiento de las mujeres empresarias: una visión global”, Revista de Economía Mundial Universidad de Huelva.

HAmilton, L. (2003), "Competitive advantages and the smes: the role of distinctive competences as determinants of success, are there differences across gender, sector, and size?" (Dissertation/Thesis) Universitat Autònoma de Barcelona.

HENLEY, A. (2007), "Entrepreneurial aspiration and transition into selfemployment: evidence from British longitudinal data", Entrepreneurship \& Regional Development, Vol. 19(3), pp. 253-280. doi: 10.1080/ 08985620701223080

Hughes, K. D., J.R. Jennings, C. Brush, S. CArter and F. Welter (2012), "Extending Women's Entrepreneurship Research in New Directions", Entrepreneurship: Theory \& Practice, Vol. 36(3), pp. 429-442. doi: 10.1111/j.1540-6520.2012.00504.x. 
Kelley, D., C. Brush, P. Green and Y. Litovsky (2013), "Global Entrepreneurship Monitor 2012 Women's Report”, Global Entrepreneurship Monitor, Babson College.

LeE, E. and M. Vivarelli (2006), "The social impact of globalization in the developing countries", International Labour Review, Vol. 145(3), pp. 167.

Loscocco, K. A., J. Robinson, R.H. HALl and J.K. Allen (1991), "Gender and Small Business Success: An Inquiry into Women's Relative Disadvantage", Social Forces, Vol. 70(1), pp. 65.

Manolova, T. S., C.G. Brush and L.F. Edelman, (2008), "What do women entrepreneurs want?”, Strategic Change, Vol. 17(3/4), pp. 69-82, doi: $10.1002 /$ jsc. 817 .

MARKOVIĆ, M.R. (2007). (Ed.). (2007), “The perspective of women's entrepreneurship in the age of globalization", IAP.

Minniti, M. (2010), "Female Entrepreneurship and Economic Activity", European Journal of Development Research, Vol. 22(3), pp. 294. doi: 10.1057/ejdr.2010.18.

Noguera, M., C. Álvarez, D. Ribeiro and D. Urbano (2013), "Sociocultural Factors and Female Entrepreneurship in the Innovative Service Sector in Catalonia: A Qualitative Analysis", in J. J. M. Ferreira, M. Raposo, R. Rutten and A. Varga (Eds.), Cooperation, Clusters, and Knowledge Transfer, pp. 141-162, Springer Berlin Heidelberg.

QueVedo, L., J. IZAR and L. Romo (2010), "Factores endógenos y exógenos de mujeres y hombres emprendedores de España, Estados Unidos y México", Investigación y Ciencia, Vol. 18(46), pp. 57-63.

RAE, D. (2014), “Graduate entrepreneurship and career initiation in the 'New Era' economy”, Journal of General Management, Vol. 40(1), pp. 79-95.

Reynolds, P., N. Bosma, E. Autio, S. Hunt, N. De Bono, I. Servais, P. LóPez and N. ChIN (2005), "Global Entrepreneurship Monitor: Data Collection Design and Implementation 1998-2003", Small Business Economics, Vol. 24(3), pp. 205-231. doi: 10.1007/s11187-005-1980-1. 
RIDING, A. L. (2008), "Business angels and love money investors: segments of the informal market fo r risk capital", Venture Capital, Vol. 10(4), pp.355-369. doi: 10.1080/13691060802351222

Romaní, G., M. ATIENZA AND J.E. AMORÓs. (2012), “Informal investors in Chile: an exploratory study from a gender perspective", Journal of Business Economics and Management, Vol. 13(1), pp.111-131.

Romaní, G., M. AtienZA And J.E. Amorós. (2012), "Informal investors in Chile: an exploratory study from a gender perspective", Journal of Business Economics and Management, Vol. 13(1), pp.111-131.

Schwartz, E. B. (1976), "Entrepreneurship: a new female frontier", Journal of Contemporary Business, Seattle, Vol. 5(1), pp.. 47-76.

ShaH, N. and A. SoOmro (2015), "Developing attitudes and intentions among potential entrepreneurs", Journal of Enterprise Information Management, Vol. 28(2).

SteVenson, H. (2006), “A Perspective on Entrepreneurship", Harvard Business Review.

TERJESEN, S. and J.E. Amorós (2010), "Female Entrepreneurship in Latin America and the Caribbean: Characteristics, Drivers and Relationship to Economic Development", European Journal of Development Research, Vol. 22(3), pp. 313. doi: 10.1057/ejdr.2010.13.

Urbano, D. and C. Álvarez (2014), "Institutional dimensions and entrepreneurial activity: an international study", Small Business Economics, Vol. 42(4), pp. 703-716. doi: 10.1007/s11187-013-9523-7.

Ventura FERnÁndez, R. and M.J. Quero Gervilla (2013), "Factores explicativos de la intención de emprender en la mujer", Aspectos diferenciales en la población universitaria según la variable género.

Verheul, I., M. CARreE and R. THURIK (2009), “Allocation and productivity of time in new ventures of female and male entrepreneurs", Small Business Economics, Vol. 33(3), pp. 273. doi: 10.1007/s11187-009-9174-X.

WeEKS, J. and D. SEILER (2001), “Women's entrepreneurship in Latin America : an exploration of current knowlede", Inter-American Development Bank. 
Wilson, F., J. KicKUL AND D. MARLino (2007), “Gender, Entrepreneurial SelfEfficacy, and Entrepreneurial Career Intentions: Implications for Entrepreneurship Education", Entrepreneurship: Theory and Practice, Vol. 31(3), pp. 387. doi: 10.1111/j.1540-6520.2007.00179.x

Wry, T., M. LOUNSBURY and M.A. GLYNN (2011), "Legitimating Nascent Collective Identities: Coordinating Cultural Entrepreneurship", Organization Science, Vol. 22(2), pp. 449. doi: 10.1287/orsc.1100.0613. 
